\title{
Abundance, distribution and conservation of Rio Branco Antbird Cercomacra carbonaria and Hoary-throated Spinetail Synallaxis kollari
}

\author{
MARIANA M. VALE, J. BRUCE BELL, MARIA ALICE S. ALVES and STUART L. \\ PIMM
}

\begin{abstract}
Summary
Cercomacra carbonaria and Synallaxis kollari are passerine birds endemic to the gallery forests of Roraima state in northernmost Brazil and adjacent Guyana. The IUCN Red List of Threatened Species lists both as Vulnerable but they have been removed from Brazil's list of threatened species because of data deficiency. They are poorly known, reflecting both Roraima state's distance from Brazil's main population centres and the inaccessibility of their habitat. In 2004 and 2005, we conducted bird surveys along the major rivers that provided previous sightings, and expanded records from only a handful to several dozens. We found C. carbonaria at $29 \%$ of the points surveyed, and estimated its local population density at approximately 80 individuals $\mathrm{km}^{-2}$ and total population size to exceed 15,000 individuals. The species has $723 \mathrm{~km}^{2}$ of available habitat, $8 \%$ of which is inside conservation units. We found S. kollari at $44 \%$ of the points surveyed, and estimated its local population density as approximately 60 individuals $\mathrm{km}^{-2}$, with an estimated total population size exceeding 5,00o individuals. It has $206 \mathrm{~km}^{2}$ of available habitat, none of which is inside conservation units. We recommend that C. carbonaria be downlisted on the IUCN Red List to the Near Threatened category, and that S. kollari be listed as Endangered. Both species live in areas vulnerable to habitat loss. We also recommend that both species re-enter the Brazilian list of threatened species and highlight the importance of indigenous reserves to their conservation.
\end{abstract}

\section{Resumo}

Cercomacra carbonaria e Synallaxis kollari são aves passeriformes das matas de galeria do Estado de Roraima em sua parte mais ao norte do Brasil e da Guiana adjacente. Ambas as espécies são catalogadas como "Vulneráveis" pela lista vermelha de espécies ameaçadas da IUCN, mas foram excluídas da lista de espécies ameaçadas do Brasil devido à insuficiência de dados. Estas espécies são pouco conhecidas, refletindo tanto a distância do Estado de Roraima dos principais centros urbanos quanto a inacessibilidade do seu hábitat. Em 2004 e 2005, realizamos censos de aves anteriormente avistadas ao longo de rios maiores, aumentando assim os registros de apenas alguns poucos números para diversas dezenas. Encontramos C. carbonaria em $29 \%$ dos pontos amostrados e estimamos sua densidade local em $\sim 80$ indivíduos $\mathrm{km}^{-2}$ e o tamanho populacional total em mais de 15.000 indivíduos. A espécie possui $723 \mathrm{~km}^{2}$ de habitat disponível, $8 \%$ do qual está incluído em unidades de conservação. Encontramos S. kollari em $44 \%$ dos pontos amostrados e estimamos sua densidade populacional local em $\sim 60$ indivíduos $\mathrm{km}^{-2}$, com uma estimativa de tamanho populacional total em mais de 5,000 indivíduos. Esta espécie tem $206 \mathrm{~km}^{2}$ de habitat disponível, nenhum dos quais incluído em unidades de conservação. Recomendamos que C. carbonaria seja rebaixada para a categoria 'Quase Ameaçada' e S. kollari categorizada 
como 'Ameaçada' na lista vermelha da IUCN. Ambas as espécies vivem em áreas vulneráveis em relação à perda de seu hábitat. Recomendamos, também, que ambas as espécies sejam reincluídas na lista de espécies ameaçadas do Brasil, destacando a importância das reservas indígenas para a sua conservação.

\section{Introduction}

Roraima state is located in extreme northern Brazil, bordering Venezuela to the north and west, Guyana to the north and east, and Amazonas state to the south. Roraima has a more heterogeneous vegetation than would be expected from its location in the Amazon Basin, including evergreen tropical forests, semi-deciduous forests, swamps, white sand forests (campina and campinarana) and savannas (lavrado) (Furley and Mougeot 1994). Nearly all water bodies in the savannas are fringed by gallery forests, which do not flood during the highwater season (unlike várzea forest) and are characterized by shrubby vegetation with a dense understorey dominated by vines. Stattersfield et al. (1998) identified the Rio Branco gallery forest of Roraima as an Endemic Bird Area (EBA 063) based on the presence of two endemic passerines specialized to this linear riverine habitat: the Rio Branco Antbird (Cercomacra carbonaria) and the Hoary-throated Spinetail (Synallaxis kollari). Wege and Long (1995) recognize four Key Areas for Threatened Birds within the Rio Branco gallery forest EBA: Boa Vista and Rio Mucajaí, based on the presence of $C$. carbonaria, and Conceição do Mau and Rio Surumu, based on the presence of S. kollari. Although these key areas are in the northern, more populated, portion of the state, they are not formally protected within conservation units.

According to the map of Monteiro and Sawyer (2001), which combines demographic and socio-economic indices, Boa Vista, Rio Surumu and Rio Mucajaí are in the counties with the highest anthropogenic pressures in Roraima state. Conceição do Mau, a small town within the Raposa Serra do Sol Indigenous Reserve, is subject to lower levels of such pressures.

Zimmer et al. (1997) identified uncontrolled fires and conversion to rice production as the main threats facing the gallery forests of Roraima. Since their assessment, however, the establishment of new rice plantations along riverbanks has increased dramatically (Cordeiro 2005) and these are now the single major threat to these forests.

Cercomacra carbonaria occurs in the gallery forests along the entire Rio Branco and its major tributaries, while S. Kollari is restricted to the tributaries (Remsen 2003, Zimmer and Isler 2003, Naka et al. 2006). Parker et al. (1996) considered C. carbonaria to be "fairly common" and S. kollari "probably rare" and ranked both species as a medium-level priority for research and conservation. IUCN lists both species as Vulnerable based on their estimated small ranges, continuing habitat loss and population decline (IUCN 2004, BirdLife International 2006a, b). Information about these species is still very limited, as evidenced by the quality of the data available to assess their conservation status (BirdLife International 2006a, b). The only pertinent literature published since the Collar et al. (1992) assessment is a study on C. carbonaria vocalization and behaviour (Zimmer et al. 1997) and a few additional records (Forrester 1992, Stotz 1997, Grosset and Minns 2002, Santos 2003). As a consequence of clear deficiency in data, C. carbonaria and S. kollari were removed from Brazil's most recent official list of threatened species (Brasil 2003, Machado et al. 2005).

Following the recommendations of Collar et al. (1992), we investigated both C. carbonaria and S. kollari to revise and offer new information on the species' geographic range limits, investigate abundance at the local and regional levels, and estimate available habitat and global population size.

\section{Methods}

Bird surveys: regional abundance

Following explorations in July 2003, we conducted fieldwork from 10 July to 24 August 2004. These months represent the height of the Roraima rainy and high water level season (Barbosa 
1997), which coincide with the breeding season of both species (Zimmer et al. 1997, Vale et al. 2005). Here we use the terms "right bank" and "left bank" according to the traditional Amazonian system, based on the hand each bank faces when descending the watercourse (Whittaker and Oren 1999).

We determined the presence or absence of $C$. carbonaria and S. kollari along the major rivers where they occur with field assistance of a very experienced boatman, Claudiomiro Parente (C. P.). We surveyed $157 \mathrm{~km}$ on the right bank of the mid- and lower Rio Uraricoera, $114 \mathrm{~km}$ on the right bank of the mid- and lower Rio Tacutu, and $70 \mathrm{~km}$ on the left bank of the mid- and lower Rio Surumu (Figure 1A). On 13 July 2005 we surveyed an additional point on the Rio Uraricoera, $3 \mathrm{~km}$ away from the uppermost point surveyed in 2004, where C. P. reported hearing both species in August 2003.

We used a boat to survey the strip of gallery forest along these rivers, stopping every $3 \mathrm{~km}$ to perform playback. At each point, we broadcast a 3:47 minute pre-set sequence of vocalization intercalated with silence for each species using a Sony TCM-50oo EV tape recorder. C. carbonaria's sequence was always broadcast before $S$. kollari's. We created the sequence in the computer using a commercial recording of C. carbonaria's song (Isler and Whitney 2002) and a recording of S. kollari's song made by Jeremy Minns (Grosset and Minns 2002). Each point was visited only once. No work was done under rainy or windy conditions.

$61^{\circ} 33^{\prime} \mathrm{W} \quad 61^{\circ} 21^{\prime} \mathrm{W} 61^{\circ} 9^{\prime} \mathrm{W} \quad 60^{\circ} 57^{\prime} \mathrm{W} \quad 60^{\circ} 45^{\prime} \mathrm{W} \quad 60^{\circ} 33^{\prime} \mathrm{W} \quad 60^{\circ} 21^{\prime} \mathrm{W} \quad 60^{\circ} 9^{\prime} \mathrm{W} \quad 59^{\circ} 57^{\prime} \mathrm{W} \quad 59^{\circ} 45^{\prime} \mathrm{W}$

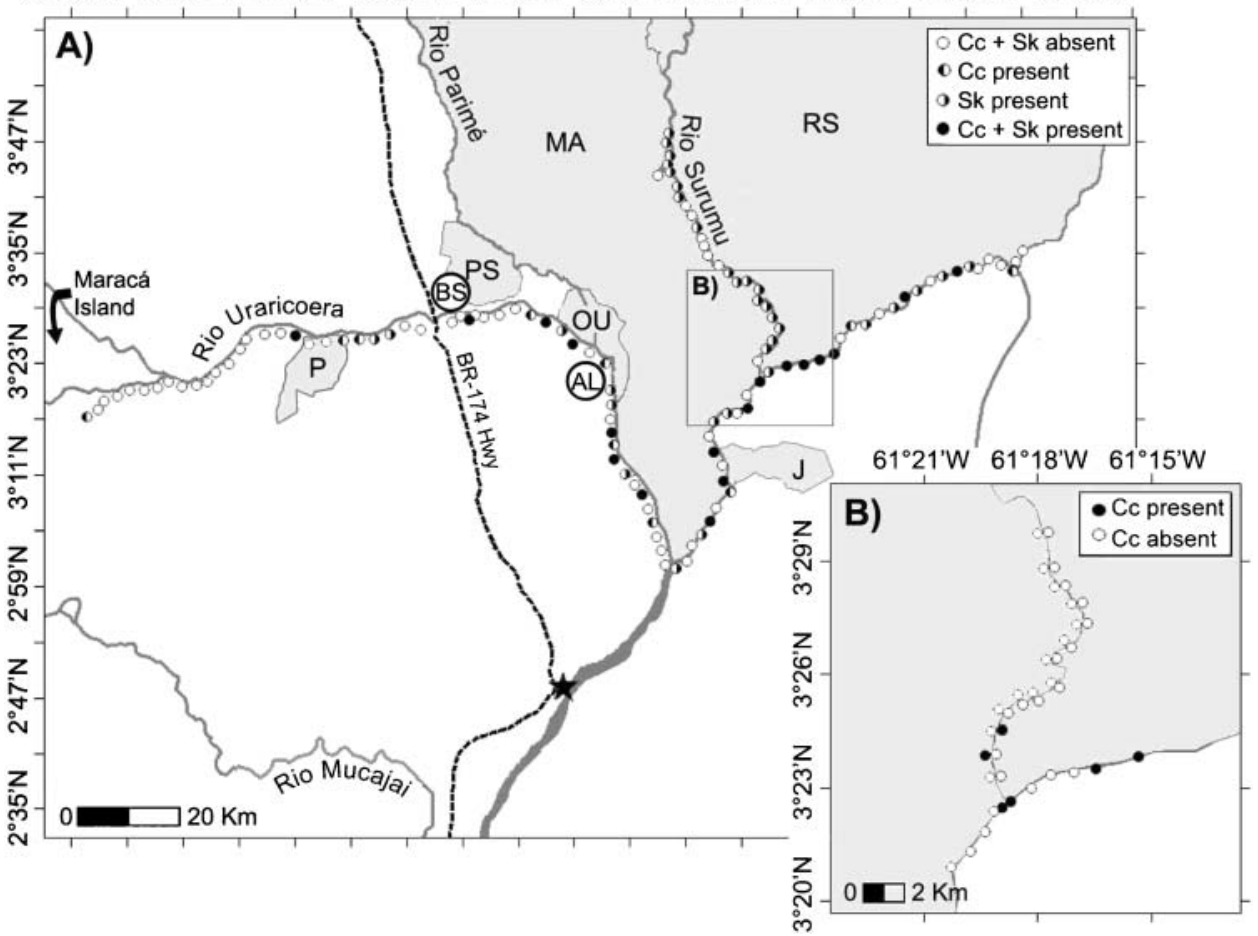

Figure 1. Regional abundance survey. (A) Rio Uraricoera, Rio Tacutu and Rio Surumu survey (3 $\mathrm{km}$ sampling regime). (B) Rio Surumu survey ( $\mathrm{km}$ sampling regime). Species: Cc, Cercomacra carbonaria; Sk, Synallaxis kollari's. Local abundance survey localities: AL, Alagadiço; BS, Bridge site. Indigenous Reserves within species range (grey): J, Jaboti Indigenous Reserve; OU, Ouro Indigenous Reserve; P, Pium Indigenous Reserve; PS, Ponta da Serra Indigenous Reserve; RS, Raposa Serra do Sol Indigenous Reserve; MA, São Marcos Indigenous Reserve. 
We used playback to improve our chances of detecting the birds. Playback is especially recommended for secretive species and dense habitats (Johnson et al. 1981), which is the case for both species studied. The preferred habitat of $C$. carbonaria and S. kollari is nearly impenetrable (Zimmer et al. 1997), and although both species are secretive, we found in our 2003 explorations that they respond well to playback.

We divided the number of points where a species was present by the total points surveyed to estimate of the probability of finding the species in a given site within its geographic range. It is important to note that although presence data are definite, absence data are not. If a given species responded to playback, we were sure it was present at that point but if it did not respond it could either have been absent or present but unresponsive. Therefore, our estimate of the probability of finding a species in a given site is likely to be underestimated.

\section{Bird surveys: local abundance}

We used playback counts to estimate local abundance (Bibby et al. 200o). The fieldwork on local abundance ran from 1o July to 5 August 2004. The surveys took place in two sites on the Rio Uraricoera: 'Alagadiço' and 'Bridge' sites (Figure $1 \mathrm{~A}$ ). Both sites had a strip of dense gallery forest dominated by shrubs and vines, with an average canopy height of $4 \mathrm{~m}$, and a sharp edge with savanna originally converted to rice plantation and cattle pasture and subsequently abandoned. We chose these sites based on the confirmed presence of both species in July 2003 exploratory surveys. Alagadiço $\left(\mathrm{O}^{\circ} 22^{\prime} \mathrm{N}, 60^{\circ} 35^{\prime} \mathrm{W}\right)$ is located on the right bank of the Uraricoera River, inside Fazenda Truarú, a farm $67 \mathrm{~km}$ north of Boa Vista. The patch of forest surveyed at Alagadiço was $4 \mathrm{~km}$ long, had an area of $39.6 \mathrm{ha}$, and a width ranging from 3 to 300 $\mathrm{m}$. This site was relatively undisturbed by human visitation, having at the time of the study only one household within the $330 \mathrm{~km}^{2}$ of Fazenda Truarú. The Bridge site $\left(03^{\circ} 27^{\prime} \mathrm{N}, 60^{\circ} 54^{\prime} \mathrm{W}\right)$ is 86 $\mathrm{km}$ north of Boa Vista, on the left margin of the Rio Uraricoera near the BR-174 highway bridge that spans the river. The patch of gallery forest surveyed at the Bridge site was $3.5 \mathrm{~km}$ long, had an area of $37.5 \mathrm{ha}$, and a width ranging from 11 to $220 \mathrm{~m}$.

At both sites, we flagged points at $200 \mathrm{~m}$ intervals, as suggested in Hutto et al. (1986) and Gutzwiller (1991), along a pre-existing trail parallel to the inland margin of the gallery forest. We surveyed the maximum number of points we could fit into each patch of gallery forest: 20 points $(4 \mathrm{~km})$ in Alagadiço and 17 points $(3.5 \mathrm{~km})$ in the Bridge site. Each site was visited three times. During each visit, two surveys were carried out by two observers starting at the same time from opposite ends of the line, such that each point was surveyed twice in each visit. The three visits and two surveys per visit yielded six surveys per site.

The surveys started at o8hoo and took 3-5 hours to complete. We standardized the time spent at each point by the length of the playback (3:47 minutes). In contrast, the time spent between points varied considerably between sites and observers due to heterogeneity in terrain condition and observers' travel speed. In the field, the observer broadcasted the same pre-set vocalizations used at the regional survey at each survey point, recording all individuals heard or seen within $100 \mathrm{~m}$ from the observer during the playback.

\section{Bird surveys: geographic range limits}

We determined the species geographic range limits from: (1) the literature, (2) fieldwork carried out in 2004 during the regional abundance bird survey (mentioned above), and (3) fieldwork carried out in 2005 in key areas, using the same $3 \mathrm{~km}$ and playback sampling regime as in the regional abundance survey.

Between 5 and 14 September 2005, we surveyed $23 \mathrm{~km}$ upriver on the Rio Mau starting at the uppermost record in this river for C. carbonaria and S. kollari ( $\mathrm{O}^{\prime}$ Shea et al. 2007), $55 \mathrm{~km}$ upriver on the Rio Mucajaí starting at the uppermost record for C. carbonaria on this river 
(Santos 2003), and $46 \mathrm{~km}$ upriver on the Rio Parimé starting at its mouth with the Rio Uraricoera.

\section{Data analysis: local population density}

We used the local abundance data to estimate population density at the Alagadiço and Bridge sites. The total number of individuals at a site $(n)$ was defined as the sum of the maximum number of individuals recorded at each point surveyed for that site. While Zimmer et al. (1997) recorded $C$. carbonaria female response to playback, in our study only males responded. This may be a consequence of female occupation with nesting duties during the breeding season. There is no sexual dimorphism in S. kollari and we do not know of differential response to playback vocalization (Grosset and Minns 2002). In Manú National Park, Peru, both male and female of the genera Synallaxis respond to playback (J. Terbough, pers. comm. 2006). We considered that both male and female $S$. kollari responded to playback, using the total number of individuals recorded as the estimate of the number $S$. kollari individuals at each site. We therefore used the total number of individuals recorded for S. kollari estimates and twice the total number recorded for C. carbonaria estimates.

Both species often came close to the observer without vocalizing in response to broadcasting. This usually enabled first detection just a few metres from the observer. Therefore, the distance between the observer and the bird was omitted from population density estimates, as it would artificially inflate the estimate. At each point, we only recorded birds that were within a $100 \mathrm{~m}$ radius, considering birds beyond this distance as belonging to adjacent points.

We calculated male population density $(D)$ per site as the total number of individuals $(n)$ divided by the area surveyed, that area being within a $100 \mathrm{~m}$ radius of the survey point.

We used regression and one-way ANOVA to test whether the number of missed individuals at a given point was influenced by: (I) the time of day at which the point was surveyed, and (2) whether it was the first or second time this point had been surveyed that day. We estimated the number of individuals missed per point in each survey by subtracting the number of individuals recorded at each point in that survey from the maximum number of individuals recorded for that point in all surveys. The regression of the number of individuals missed against the time of day revealed no relationship for any of the species in either site $\left(r^{2}{ }_{\max }<0.01, P_{\min }>0.05\right)$, possibly because point counts supplemented by playback equalize detection rates at different times of day (Sliwa and Sherry 1992). At both sites and for both species, a single-factor ANOVA showed no difference in number of missed individuals in points surveyed for the first versus second time that point was surveyed (ANOVA $P_{\min }>0.05$ ), which indicates that the simultaneous surveys did not influence the results.

\section{Data analysis: available habitat and global population size}

Zimmer et al. (1997) consider C. carbonaria habitat to be confined to $0.5 \mathrm{~km}$ from the riverbanks where the species occur. Because $S$. kollari is believed to share the same habitat as $C$. carbonaria, we used the Zimmer et al. (1997) assessment of habitat for both species. We determined the potential available habitat as the entire area within $0.5 \mathrm{~km}$ from water, either along riverbanks or islands, within the known geographic range of the species. We used three mosaics of Landsat images (Mr-Sid N-20-OO, N-21-0O, S-20-OO) and geographic information system (GIS) buffering techniques. These mosaics are from year 2000, cover an area of $555 \mathrm{~km} \times 768 \mathrm{~km}$, and have a resolution of $14.25 \mathrm{~m}$.

From the total potential habitat, we visually identified and removed areas that did not correspond to gallery forest, which is the preferred habitat of C. carbonaria and S. kollari. We divided the non-gallery-forest areas (hereafter called 'non-habitat') into natural landscapes (savanna, sand banks and water bodies) and human-modified landscapes (urban areas, roads and farms). We calculated available habitat as the total potential habitat area minus the non-habitat 
areas. Although the visual identification of habitat and non-habitat areas is straightforward, the distinction between natural and human-modified non-habitat areas can be subjective and the results should be interpreted with caution.

We calculated the area of available habitat within conservation units and indigenous reserves using the GIS database of the SIGLAB at the Instituto Nacional de Pesquisas da Amazônia (INPA) and the online interactive maps of Instituto Socioambiental.

We multiplied the available habitat by the mean population density (between Alagadiço and Bridge sites) to estimate species' maximum global population size. This is the maximum global population because it considers the entire available habitat to be occupied by the species. We calculated a minimum global population size by multiplying the available habitat by the probability of finding the species in a given site. This is a minimum population size because the probability of finding the species in a given site is likely to be underestimated. The species' global population size should lie somewhere between the estimated maximum and minimum population size.

\section{Results}

\section{Regional abundance}

S. kollari was present at $44 \%$ of the 121 points surveyed during the 2004 fieldwork, being most common along the Rio Surumu (67\% of 27 points surveyed), followed by the Rio Tacutu $(54 \%$ of 41 points) and the Rio Uraricoera ( $36 \%$ of 36 points surveyed up to the species' range limit on this river). C. carbonaria was present in $24 \%$ of the 121 points surveyed, being more abundant on the Rio Tacutu ( $37 \%$ of 41 points surveyed), followed by the Rio Uraricoera ( $12 \%$ of 53 points) and absent from the Rio Surumu (Figure IA). To confirm the absence of $C$. carbonaria from the Rio Surumu, we revisited this river 21 days later, stopping every $1 \mathrm{~km}$ on both margins for $16 \mathrm{~km}$. In the second, more thorough, survey of the Rio Surumu we found C. carbonaria at three points, the one farthest upriver being only $2.8 \mathrm{~km}$ away from the mouth of the Surumu $\left(03^{\circ} 24^{\prime} \mathrm{N}, 60^{\circ} 19^{\prime} \mathrm{W}\right)$ (Figure $\left.1 \mathrm{~B}\right)$.

\section{Local abundance}

Table 1 shows the number of individuals recorded and the estimated population density for Alagadiço and the Bridge sites. S. kollari had a mean density estimate of approximately 60 individuals $\mathrm{km}^{-2}$ and C. carbonaria of approximately 75 individuals $\mathrm{km}^{-2}$. The Bridge site had the highest male population density for both species (Table 1 ).

Both C. carbonaria and S. kollari were responsive to playback. S. kollari was especially bold, sometimes positioning itself less then I metre away from the observer. Sightings (as opposed to hearings) represented $29 \%$ of C. carbonaria records and $46 \%$ of S. kollari records. We commonly recorded solitary individuals of both species (70\% of C. carbonaria and $55 \%$ of $P$.

Table 1. Abundance of Cercomacra carbonaria and Synallaxis kollari in the Alagadiço (20 survey points) and Bridge ( 17 survey points) sites.

\begin{tabular}{llllll}
\hline Site & \multicolumn{2}{l}{ Cercomacra carbonaria } & & \multicolumn{2}{l}{ Synallaxis kollari } \\
\cline { 2 - 3 } \cline { 5 - 6 } & $n$ & $D$ & & \\
\hline Alagadiço & $42^{a}$ & 67 & 35 & 5 \\
Bridge & $44^{a}$ & 82 & 34 & 56 \\
Mean & 43 & 76 & 34.5 & 64 \\
\hline
\end{tabular}

$N$, number of individuals recorded; $D$, population density expressed as individuals $/ \mathrm{km}^{2}$.

${ }^{\mathrm{a}}$ Twice the number of male individuals. 
kollari records) and paired individuals (27\% of C. carbonaria and $39 \%$ of P. kollari records). The maximum group size was three individuals for $C$. carbonaria and five for $S$. kollari.

\section{Geographic range limits}

Table 2 presents the distribution of both species from the literature and data herein. In the 2004 survey, M. M. V. and J. B. B. recorded both C. carbonaria and S. kollari up to $111 \mathrm{~km}$ on the Rio Uraricoera $\left(03^{\circ} 28^{\prime} \mathrm{N}, 61^{\circ} \mathrm{Og}^{\prime} \mathrm{W}\right)$. The surveys detected neither species at the remaining 16 points surveyed upriver (c. $46 \mathrm{~km})$. This is the most upstream record of S. kollari on the Rio Uraricoera to date. On 13 July 2005, M. M. V. and S. L. P. confirmed the presence of two C. carbonaria males at a point $3 \mathrm{~km}$ farther upstream than the farthest point surveyed in 2004 $\left(03^{\circ} 18^{\prime} \mathrm{N}, 61^{\circ} 31^{\prime} \mathrm{W}\right)$, as reported by C. P. The record was on the right bank of the Rio Uraricoera, approximately $24 \mathrm{~km}$ upriver from the easternmost tip of Maracá Island, in an area highly disturbed by cattle ranching. This is the farthest upstream record to date for $C$. carbonaria on the Rio Uraricoera.

Table 2. Geographic range limits, available habitat, and area within conservation and indigenous reserves for Cercomacra carbonaria and Synallaxis kollari.

\begin{tabular}{|c|c|c|c|c|}
\hline River & Geographic range & Length $(\mathrm{km})$ & Habitat $\left(\mathrm{km}^{2}\right)$ & Area within reserve $(\%)$ \\
\hline \multicolumn{5}{|c|}{ Cercomacra carbonaria } \\
\hline Branco & $\begin{array}{l}\text { Source }{ }^{a} \text { down to o1 }{ }^{\circ} 16^{\prime} \mathrm{S} / \\
61^{\circ} 50^{\prime} \mathrm{W}^{(1)}\end{array}$ & 562 & $467(11)$ & $18 \%(\mathrm{VNP}, \mathrm{CSP}, \mathrm{NSP})$ \\
\hline Mau & $\begin{array}{l}\text { Mouth up to } 03^{\circ} 42^{\prime} \mathrm{N} / \\
59^{\circ} 4 \mathrm{O}^{\prime} \mathrm{W}^{(2)}\end{array}$ & 80 & 25 & $54 \%(\mathrm{RS})$ \\
\hline Mucajaí & $\begin{array}{l}\text { Mouth up to } 02^{\circ} 41^{\prime} \mathrm{N} / \\
61^{\circ} 16^{\prime} \mathrm{W}^{(3)}\end{array}$ & 95 & 68 & o \\
\hline Tacutu & $\begin{array}{l}\text { Mouth up to } 03^{\circ} 34^{\prime} \mathrm{N} / \\
59^{\circ} 53^{\prime} \mathrm{W}^{(4)}\end{array}$ & 120 & $36(1)$ & $57 \%(\mathrm{RS}, \mathrm{MA}, \mathrm{J})$ \\
\hline Uraricoera & $\begin{array}{l}\text { Mouth up to } 03^{\circ} 18^{\prime} \mathrm{N} / \\
61^{\circ} 31^{\prime} \mathrm{W}^{(5)}\end{array}$ & 169 & $102(13)$ & $65 \%(\mathrm{MA}, \mathrm{OU}, \mathrm{P})$ \\
\hline \multicolumn{5}{|c|}{ Synallaxis kollari } \\
\hline Cotingo & $\begin{array}{l}\text { Mouth up to } 04^{\circ} 10^{\prime} \mathrm{N} / \\
60^{\circ} 32^{(6)}\end{array}$ & 46 & 8 & $100 \%(\mathrm{RS})$ \\
\hline Mau & $\begin{array}{l}\text { Mouth up to } 03^{\circ} 42^{\prime} \mathrm{N} / \\
59^{\circ} 4 \mathrm{O}^{\prime} \mathrm{W}^{(2)}\end{array}$ & 80 & 25 & $54 \%(\mathrm{RS})$ \\
\hline Parimé & $\begin{array}{l}\text { Mouth up to } 03^{\circ} 34^{\prime} \mathrm{N} / \\
60^{\circ} 44^{\prime} \mathrm{W}^{(5)}\end{array}$ & 46 & 10 & $70 \%(\mathrm{MA}, \mathrm{PS}, \mathrm{OU})$ \\
\hline Surumu & $\begin{array}{l}\text { Mouth up to } 04^{\circ} 12^{\prime} \mathrm{N} / \\
60^{\circ} 48^{\prime} \mathrm{W}^{(7)}\end{array}$ & 183 & 42 & $100 \%(\mathrm{RS}, \mathrm{MA})$ \\
\hline Tacutu & $\begin{array}{l}\text { Mouth up to } 03^{\circ} 34^{\prime} \mathrm{N} / \\
59^{\circ} 53^{\prime} \mathrm{W}^{(4)}\end{array}$ & 120 & $36(1)$ & $57 \%(\mathrm{RS}, \mathrm{MA}, \mathrm{J})$ \\
\hline Uraricoera & $\begin{array}{l}\text { Mouth up to } 03^{\circ} 28^{\prime} \mathrm{N} / \\
61^{\circ} \mathrm{og}^{\prime} \mathrm{W}^{(5)}\end{array}$ & 116 & $71(13)$ & $88 \%(\mathrm{MA}, \mathrm{OU}, \mathrm{P})$ \\
\hline
\end{tabular}

Geographic range, species' upper and lower range limits along rivers; Length, extent of range along rivers; Habitat, area of available habitat along rivers within riverbanks and (islands).

Sources of geographic range limit data: (1) 1o km upriver from mouth of Rio Branco, Brazil (Naka et al. 2006), (2) Good Hope, Guyana (O'Shea et al. 2007), (3) Fazenda Paraense, Brazil (Santos 2003), (4) near Conceição do Mau, Brazil (Forrester 1992), (5) data herein, (6) near Contão, Brazil (Grosset and Minns 2002), (7) near Surumu town, Brazil (Grosset and Minns 2002).

Reserves: CSP, Caracaraí State Park; NSP, Niquiá State Park; VNP, Viruá National Park (see Figure 1 for indigenous reserves).

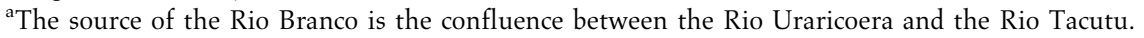


On 5 September 2005, M. M. V. failed to record C. carbonaria or S. kollari individuals upriver from their previous uppermost record in the Rio Mau (Good Hope - Guyana, $3^{\circ} 53^{\prime} \mathrm{N}, 59^{\circ} 35^{\prime} \mathrm{W}$; $\mathrm{O}^{\prime}$ Shea et al. 2007). Likewise, on 14 September 2005 M. M. V. recorded no individuals upriver from the uppermost records of C. carbonaria in the Rio Mucajaí (Fazenda Paraense - Brazil, $2^{\circ} 41^{\prime} \mathrm{N}, 61^{\circ} 16^{\prime} \mathrm{W}$; Santos 2003). Therefore, we have confirmed the known uppermost records for the species in the Rio Mucajaí and Rio Mau.

On 7 September 2005, M. M. V. recorded C. carbonaria individuals up to $4 \mathrm{~km}\left(03^{\circ} 25^{\prime} \mathrm{N}\right.$, $\left.60^{\circ} 36^{\prime} \mathrm{W}\right)$ and S. kollari up to $35 \mathrm{~km}\left(\mathrm{O}^{\circ} 34^{\prime} \mathrm{N}, 60^{\circ} 44^{\prime} \mathrm{W}\right)$ from the mouth of the Rio Parimé. These are the first records for both species on the Rio Parimé and represent their known geographic limits on this river.

We do not consider C. carbonaria to occur in the Rio Parimé and Rio Surumu, nor S. kollari to occur in the Rio Branco. Our study shows that $C$. carbonaria occurrence in the Rio Parimé and Rio Surumu is restricted to the area a few kilometres from the respective mouths of these rivers and, thus, should be considered within the influence of the Rio Uraricoera and Rio Tacutu, respectively. Similarly, the only S. kollari record in the Rio Branco is on Forte São Joaquim (J. Natterer 1836, Vienna Museum of Natural History), at about 1 km from the Rio Branco's source (the confluence of the Rio Uraricoera and Rio Tacutu), and should be considered under the influence of the Rio Tacutu.

\section{Available habitat and global population size}

Table 2 shows the amount of available habitat for C. carbonaria and S. kollari along the rivers at which they occur. C. carbonaria has $723 \mathrm{~km}^{2}$ of available habitat (gallery forest), with only 25 $\mathrm{km}^{2}$ of this within islands (Table 2). The available habitat represents $72 \%$ of the species' potential habitat (all habitat within $0.5 \mathrm{~km}$ from the river margin). The non-habitat is mostly covered by natural landscapes (savanna, sand beaches and water bodies), but $37 \%$ is covered by human-modified landscapes (urban areas, roads and farms). Eight per cent of the available habitat of $C$. carbonaria is within conservation units and $15 \%$ within indigenous reserves (Table 2). The combination of $C$. carbonaria available habitat $\left(723 \mathrm{~km}^{2}\right)$ and its population density $(75$ individuals $\mathrm{km}^{-2}$ ) translates into a maximum estimate exceeding 50,00o individuals. If we factor in the species' regional abundance (found in $29 \%$ of points surveyed) we have a global population size of about 15,000 individuals.

Synallaxis kollari has $206 \mathrm{~km}^{2}$ of available habitat (gallery forest), with only $14 \mathrm{~km}^{2}$ of this within islands (Table 2). This habitat represents only $36 \%$ of the total potential habitat within the species' range. As with $C$. carbonaria, the non-habitat is mostly covered by natural landscapes, with $32 \%$ covered by human-modified landscapes. There is no S. kollari habitat within conservation units but $57 \%$ is within indigenous reserves (Table 2). The combination of available habitat $\left(206 \mathrm{~km}^{2}\right.$ ) and population density (6o individuals $\mathrm{km}^{-2}$ ) translates into a maximum estimate exceeding 12,000 individuals. If we factor in the species' regional abundance (found in $44 \%$ of points surveyed) we estimate a population size of about 5,00o individuals.

\section{Discussion}

\section{Local abundance}

Few studies of population density in riverine habitats have been attempted in the Amazon. The methods we used have obvious and well-known flaws, some of which probably cancel each other out. Logistical issues limit what we could do, of course. Circular plots suffer the obvious limitation that an $x \%$ error in estimating the maximum distance at which one regularly detects the bird, yields an approximately $x^{2} \%$ error in density. We took care to judge whether birds were inside or outside a $100 \mathrm{~m}$ radius. With circular plot methods, there is always the possibility of the systematic error of some fraction of the birds present not calling or, in this case, 
responding to the tape. This might be especially true for birds at the farthest distances from the observer. To reduce that error, we surveyed each site several times and took the maximum estimate. Clearly, if birds were not detected until we had surveyed each point several times, we might not detect all the birds present and so underestimate the correct density. In fact, for both species, for survey points that eventually held birds, we detected birds at roughly $60 \%$ on the first visit, and only $5 \%$ needed five visits to find the birds. Sixth visits detected no extra birds.

We found that the birds responded strongly to the tape and sometimes came close to it. That poses the concern that the tape might attract individuals from territories outside the $100 \mathrm{~m}$ survey radius: we would then overestimate the correct density. Our experience was that we readily heard birds up to Ioo $\mathrm{m}$ away in their habitat and the tape did not obviously bring them towards it from large distances away. Were it to be the case, it would take several surveys at each point before birds moved in and we recorded the maximum number of birds at each point. In fact, we recorded the maximum numbers at each point at $45 \%$ of the survey points (for both species) on the first visit, needing no more than five visits for $S$. kollari and six visits only at one point for C. carbonaria.

Another check on the estimates is to compare them with other studies. Taken at face value, a density of 76 and 60 individuals $\mathrm{km}^{-2}$ (roughly 38 and 30 pairs) for C. carbonaria and S. kollari, respectively, is comparable to abundance of birds in similar guilds and environments. In western Amazonia, for example, Robinson and Terborgh (1997) found that early forests along the river have significantly more common species than do mature forests inland. That these habitats were rich in arthropods explained an average density of 30 pairs (=6o birds) $\mathrm{km}^{-2}$ for understorey insectivorous species, which is strikingly similar to our estimate, all things considered.

Kratter (1995) estimated the population density of Formicarius rufifrons, a threatened bird endemic to western Amazonia. The species is similar to C. carbonaria and S. kollari in having a very small geographic range and a preferred habitat restricted to the thin strip of forest along a few rivers. There are numerous methodological differences between his study and ours, but the salient difference is the rarity of $F$. rufifrons compared with either $C$. carbonaria or $S$. kollari. Kratter found only five territories during 180 days of fieldwork - a measure of how timeconsuming his method was. He estimated population density as about 1 territory $\mathrm{km}^{-1}$ of river length surveyed or about 3 territories $\mathrm{km}^{-2}$.

In examining relative abundances, Parker et al. (1996) consider C. carbonaria to be "fairly common" and S. kollari as "probably rare" (and F. rufifrons to be "rare"). However, using their definition of "common" as those species that "occur throughout their ranges in moderate to large numbers and are found easily during brief periods of fieldwork", our results suggest that both species of the present study are locally "common".

\section{Conservation}

The greatest human threats to Roraima occur in the northern portion of the state, where the capital, Boa Vista, and most agricultural and ranching activities are located. Based on demographic and socio-economic indices, all rivers in this region, with the exception of the Rio Mau, are considered to be under pressure (Monteiro and Sawyer 2001). These include the upper Rio Branco (north of Caracaraí), Rio Uraricoera, Rio Tacutu, Rio Surumu and Rio Cotingo. The Rio Mau and the lower Rio Branco (south of Caracaraí) suffer lower pressure. Because $S$. kollari is restricted to northern Roraima, its entire available habitat is under pressure. C. carbonaria occupies large tracts of available habitat in the southern portion of its range that are under low pressure.

Birdlife International (2006a) lists C. carbonaria as Vulnerable based on its small geographical range and estimated population declines. The species is supposed to have a declining population of between 4,200 and 4,700 individuals, all within a single subpopulation (Birdlife International 2006a), based on species distribution data up to Grosset and Minns (2002). Since its initial designation, however, the known distribution of $C$. carbonaria has more than doubled through 
new records by Santos (2003) on the Rio Mucajaí, Naka et al. (2006) on the Rio Branco, O'Shea et al. (2007) on the Rio Mau and Tacutu, and the present study on the Rio Uraricoera and Rio Parimé. Of special relevance is the record by Naka et al. (2006) that extended the known distribution approximately $300 \mathrm{~km}$ southward, including large tracts of forests south of Caracaraí (previously known as the species' southernmost limit) that, as mentioned above, are under considerably less threat than those in the north (Monteiro and Sawyer 2001). C. carbonaria may, therefore, have greater ecological plasticity than previously thought, occurring in gallery forests to the north and short várzea forests to the south (Naka et al. 2006).

The increase in the known range of $C$. carbonaria should lower the species' inferred level of threat, as it probably possesses better population trends than previously thought, though the human threat is still present. The species should still remain on the Red List, where we suggest it be down-listed to Near Threatened, as it fulfils the relevant distribution criteria (it is restricted to a single river and its tributaries) and has only limited habitat protection within conservation units. Furthermore, our estimate of available habitat of $723 \mathrm{~km}^{2}$ fulfils one only of two required criteria for Vulnerable species, namely that it have an area of occupancy smaller than $2,000 \mathrm{~km}^{2}$ under continual decline (IUCN 2001). Our estimated area is about 3 times larger than that estimated by Birdlife International (2006a). It is important to note that only about $3 \%$ of $C$. carbonaria available habitat is within islands, lessening their importance for the species conservation, previously suggested by Zimmer et al. (1997).

S. kollari was listed as Endangered, as it was known to have a small range with records from only five localities (BirdLife International 2004). In the 2006 assessment, the species was downlisted to Vulnerable because of additional recent sightings (BirdLife International 2006b). We consider the down-listing to be premature: although $S$. kollari is more regionally abundant than previously thought, it still has a very small range and strict ecological requirements. Our estimate of $206 \mathrm{~km}^{2}$ of available habitat fulfils the criterion of an area of occupancy smaller than $500 \mathrm{~km}^{2}$ (IUCN 2001), which, together with a declining and fragmented habitat, makes S. kollari eligible for Endangered status. This small range is sufficient to raise considerable concerns about the species' survival. None of the $S$. kollari range is formally protected within a conservation unit, and all of it is within the region of highest anthropogenic pressure in Roraima. The gallery forests within the species' range are rapidly being converted into rice plantations. Zimmer et al. (1997) mention "some conversion to agriculture, especially rice cultivation" as a possible threat to C. carbonaria and S. kollari. In 1999, however, mechanized irrigated rice cultivation boomed in Roraima, and by 2002, the production was already 3-fold what these authors had witnessed (Cordeiro 2005). The rice plantations are concentrated on the margins of Rio Branco's main tributaries and rely heavily on fertilizers, pesticides, and herbicides (Cordeiro 2005). Local authorities have generally failed to investigate reports by local indigenous populations of occasional bird and fish die-offs near these plantations (CIR 2001, 2003). The margins of the Rio Tacutu, Rio Surumu and Rio Mau have been completely converted to rice plantations. In 2005, M. M. V. recorded 16 irrigation pipes for rice along $110 \mathrm{~km}$ of the Rio Tacutu (between its mouth and Conceição do Mau).

C. carbonaria and S. kollari were removed from Brazil's official list of threatened species (Brasil 2003) based on data deficiency (Machado et al. 2005). The present study provides enough new information for both species to be reconsidered under the Brazilian List of Threatened Species.

\section{The importance of indigenous reserves}

The role of indigenous reserves in the conservation of C. carbonaria and S. kollari has been overlooked. Previous authors systematically failed to acknowledge that most of the species records have been in indigenous reserves. Records from the Rio Uraricoera and Vila Surumu (Grosset and Minns 2002) are in the São Marcos Indigenous Reserve; while the records from Conceição do Mau (Zimmer et al. 1997, Forrester 1992), Flexal, Limão (T. D. Carter 1927, 
American Museum of Natural History) and Contão (Grosset and Minns 2002) are in the RaposaSerra do Sol Indigenous Reserve.

Most gallery forests in the northern, more disturbed, area of Roraima are within indigenous reserves. Although these are not part of the Brazilian network of conservation units, indigenous people have had a much better record of maintaining the ecosystems around them than other populations in the Amazon (Fearnside 2003, Nepstad et al. 2006). Rice cultivation is the main threat to C. carbonaria and S. kollari habitat. In Roraima, most rice production is carried out illegally by non-indigenous people within indigenous land (Rohter 2004). Producers have already been evicted from the São Marcos Indigenous Reserve but have not yet been evicted from Raposa-Serra do Sol, for which final legislation was completed on 13 April 2005. In the context of the conservation of $C$. carbonaria, and especially of $S$. kollari, the final legalization of Raposa-Serra do Sol Indigenous Reserve provides added protection.

\section{Acknowledgements}

We are indebted to Claudiomiro Parente for unmatched field assistance. We also thank Gonçalo Ferraz, Catherine Bechtoldt and Marion Adeney for help in the field; Vicenzo Lauriola, Reinaldo Barbosa and Sebastião Nascimento at the Instituto Nacional de Pesquisas Amazônicas (INPA) for logistic and strategic support; Jonas Mesquita for lending a boat for the Rio Mucajaí expedition; Mario Cohn-Haft and Luciano Naka for sharing their expertise in the region's avifauna; and Clinton Jenkins and Pedro Pedro for revising the English. Kevin Zimmer, Stuart Marsden and an anonymous referee provided valuable comments on the manuscript. We are especially grateful to David Blinken for financial support to the study since its infancy. This work was sponsored by grants to M. M. V. provided by the William and Jane Overman Foundation, the Tinker and Mellon Graduate Grant, and Sigma-Xi. M. A. S. A. received a grant from the Conselho Nacional de Desenvolvimento Científico e Tecnológico $(\mathrm{CNPq})$ whilst writing this manuscript (process no. 302718/2003-6).

\section{References}

Barbosa, R. I. (1997) Distribuição das chuvas em Roraima. Pp. 325-335 in R. I. Barbosa, E. J. G. Ferreira and E. G. Castellón, eds. Homem, ambiente e ecologia no Estado de Roraima. Manaus: INPA.

Bibby, C. J., Burgess, N. D., Hill, D. A. and Mustoe, S. (2000) Bird census techniques. Second edition. New York: Academic Press.

BirdLife International (2004) Threatened birds of the world 2004. CD-ROM. Cambridge, U.K.: BirdLife International.

BirdLife International (2006a) Species factsheet: Synallaxis kollari. Downloaded from http:// www.birdlife.org on 4 September 2006.

BirdLife International (2006b) Species factsheet: Cercomacra carbonaria. Downloaded from http://www.birdlife.org on 4 September 2006.

Brasil (2003) Instrução normativa $\mathrm{N}^{\circ}$ 3, de 27 de maio de 2003. Ministério do Meio
Ambiente. Diário Oficial da União Seção I(IOI): 88-97.

CIR - Conselho Indígena de Roraima (2001) Índios de Roraima exigem cumprimento da Constituição. CIR 13/02/2001. Downloaded from http://www.amazonia.org.br/ noticias/noticia.cfm? $\mathrm{id}=2887$ on 4 September 2006.

CIR - Conselho Indígena de Roraima (2003) Flagrante documentado de crimes ambientais na terra indígena Raposa Serra do Sol. CIR 30/04/2003. Downloaded from http:// www.amazonia.org.br/noticias/noticia.cfm? $\mathrm{id}=66358$ on 4 September 2006.

Collar, N. J., Gonzaga, L. P., Krabbe, N., Madroño Nieto, A., Naranjo, L. G., Parker, T. A. and Wege, D. C. (1992) Threatened birds of the Americas: the ICBP/IUCN Red Data Book. Cambridge, U.K.: International Council for Bird Preservation. 
Cordeiro, A. C. C. (2005) O cultivo do arroz irrigado em Roraima. Pp. $169-176$ in R. I. Barbosa, H. A. M. Xaud and J. M. C. Souza, eds. Savanas de Roraima: Etnoecologia, biodiversidade e potencialidades agrossilvipastoris. Boa Vista: FEMACT.

Fearnside, F. M. (2003) Conservation policy in Brazilian Amazonia: understanding the dilemmas. World Dev. 31: 757-779.

Forrester, B. C. (1992) Brazil's northern frontier sites: in search of two Rio Branco endemics. Cotinga 3: 51-53.

Furley, A. F. and Mougeot, L. (1994) Perspectives. Pp. $1-38$ in A. F. Furley, ed. The forest frontier: Settlement and change in Brazilian Roraima. London, U.K.: Routledge.

Grosset, A. and Minns, J. (2002) Hoarythroated Spinetail, Synallaxis kollari. Cotinga 18: 114.

Gutzwiller, K. J. (1991) Estimating winter species richness with unlimited-distance point counts. Auk 108: 853-862.

Hutto, R. L., Pletschet, S. M. and Hendricks, P. (1986) A fixed-radius point count method for nonbreeding and breeding season use. Auk 103: 593-602.

Isler, P. R. and Whitney, B. M. (2002) Songs of the Antbirds: Thamnophilidae, Formicariidae, and Conopophagidae. Disc 2 (Herpsilochmus parkeri through Myrmeciza atrothorax). Audio CD. Ithaca: Macaulay Library of Natural Sounds and Cornell Laboratory of Ornithology.

IUCN (2001) 2001 IUCN Red List Categories and Criteria. Version 3.1. Downloaded from http://www.iucnredlist.org/info/categories_criteriazoo1 on 4 September 2006.

IUCN (2004) 2004 IUCN Red List of Threatened Species. Downloaded from http://www.iucn.org/themes/ssc/red_list_ 2004/GSAexecsumm_EN.htm on 4 September 2006.

Johnson, R. R., Brown, B. T., Haight, L. T. and Simpson, J. M. (1981) Playback recordings as a special avian censuring technique. Stud. Avian Biol. 6: 68-75.

Kratter, A. W. (1995) Status, habitat, and conservation of the Rufous-fronted Antthrush (Formicarius rufifrons). Bird Conserv. Int. 5: 391-404.

Machado, A. B. M., Martins, C. S. and Drummond, G. M., eds. (2005) Lista da fauna brasileira ameaçada de extinção. Incluindo as listas das espécies quase ameaçadas e deficientes de dados. Belo Horizonte: Fundação Biodiversitas.

Monteiro, M. P. and Sawyer, D. (2001) Diagnóstico demográfico, socioeconômico e de pressão antrópica na região da Amazônia Legal. Pp. 308-320 in J. P. R. Capobianco, ed. Biodiversidade da Amazônia Brasileira. São Paulo: Instituto Socioambiental.

Naka, L. L., Cohn-Haft, M., MalletRodrigues, F., Santos, M. P. D. and Torres, M. F. M. (2006) The avifauna of the Brazilian state of Roraima: bird distribution and biogeography in the Rio Branco basin. Ararajuba: Rev. Bras. Ornit 14: 197-238.

Nepstad, D., Schwartzman, S., Bamberger, B., Santilli, M., Ray, D., Schlesinger, P., Lefebvre, P., Alencar, A., Prinz, E., Fiske, G. and Rolla, A. (2006) Inhibition of Amazon deforestation and fire by parks and indigenous lands. Conserv. Biol. 20: 67-73.

O'Shea, B. J., Milensky, C. M., Claramunt, S., Schmidt, B. K., Gebhard, C. A., Schmitt, C. G. and Erskine, K. T. (2007) New records for Guyana, with description of the voice of Roraiman Nightjar (Caprimulgus whitelyi). Bull. Br. Ornith. Club: in press.

Parker, T., Stoltz, D. and Fitzpatrick, J. (1996) Database A: zoogeography and ecological attributes of bird species breeding in the Neotropics. Pp. 131-291 in D. Stoltz, J. Fitzpatrick, T. Parker III and D. Moskovits, eds. Neotropical birds: Ecology and conservation. Chicago: University of Chicago Press.

Remsen, J. V. Jr (2003) Family Furnariidae (Ovenbirds). Pp. 286-287 in J. del Hoyo, A. Elliot and D. A. Christie, eds. Handbook of the birds of the world. Volume 8: Broadbills to Tapaculos. Barcelona: Lynx Edicions.

Robinson, S. K. and Terborgh, J. (1997) Bird community dynamics along primary successional gradients of an Amazonian whitewater river. Ornith. Monogr. 48: 641-672.

Rohter, L. (2004) Brazilians battle Indians: "This land is our land". The New York Times (15 October 2004). 
Rio Branco Antbird Cercomacra carbonaria and Hoary-throated Spinetail Synallaxis

Santos, M. P. D. (2003) Novos registros do chororó-do-Rio-Branco (Cercomacra carbonaria) no estado de Roraima, Brasil. Atualidades Ornitológicas 114: 3.

Sliwa, A. and Sherry, T. W. (1992) Surveying wintering warbler populations in Jamaica: point counts with and without broadcast vocalizations. Condor 94: 924-936.

Stattersfield, A. J., Crosby, M. J., Long, A. J. and Wege, D. C. (1998) A global directory of endemic bird areas. Cambridge, U.K.: BirdLife International.

Stotz, D. F. (1997) Levantamento preliminar da avifauna de Roraima. Pp. 581-608 in R. I. Barbosa, E. J. G. Ferreira and E. G. Castellón, eds. Homem, Ambiente e Ecologia no Estado de Roraima. Manaus: INPA.

Vale, M. M., Alves, M. A. S. and Nascimento, S. P. (2005) An incomplete nest of
Poecilurus kollari in Roraima, Brazil. Cotinga 24: 111-112.

Wege, D. C. and Long, A. J. (1995) Key areas for threatened birds in the Neotropics. Cambridge, U.K.: BirdLife International.

Whittaker, A. and Oren, D. C. (1999) Important ornithological records from the Rio Juruá, western Amazonia, including twelve additions to the Brazilian avifauna. Bull. Br. Ornith. Club 119: 235-260.

Zimmer, K. J. and Isler, M. L. (2003) Family Thamnophilidae (Typical Antbirds). Pp. 635-638 in J. del Hoyo, A. Elliot and D. A. Christie, eds. Handbook of the birds of the World. Volume 8: Broadbills to Tapaculos. Barcelona: Lynx Edicions.

Zimmer, K. J., Whittaker, A. and Stotz, D. F. (1997) Vocalization, behavior and distribution of the Rio Branco Antbird. Wilson Bull. 109: 663-678.

\section{MARIANA M. VALE*, J. BRUCE BELL, STUART L. PIMM}

Nicholas School of the Environment and Earth Sciences, Duke University, Box 90328, Durham, NC 27708-0328, USA.

\section{MARIA ALICE S. ALVES}

Departamento de Ecologia, Universidade do Estado do Rio de Janeiro, Rua São Francisco Xavier, 524, Rio de Janeiro, RJ. 20550-011, Brazil.

*Author for correspondence. e-mail: mariana.vale@duke.edu 